\title{
G20 Priorities and Decisions under Turkey's 2015 Presidency: Implementation, Inclusiveness and Investment for Strong, Sustainable and Balanced Growth
}

\author{
M. Larionova, M. Rakhmangulov, E. Safonkina, A. Sakharov, A. Shelepov ${ }^{1}$
}

\begin{abstract}
Marina Larionova - Doctor of political science, PhD in philology, Head, Centre for International Institutions Research, Russian Presidential Academy of National Economy and Public Administration; 11 Prechistenskaya naberezhnaya, 119034 Moscow, Russian Federation; E-mail: larionova-mv@ranepa.ru
\end{abstract}

Mark Rakhmangulov - Researcher, Centre for International Institutions Research, Russian Presidential Academy of National Economy and Public Administration; 11 Prechistenskaya naberezhnaya, 119034 Moscow, Russian Federation; E-mail: rakhmangulov-mr@ranepa.ru

Elizaveta Safonkina - Researcher, Center for International Institutions Research, Russian Presidential Academy of National Economy and Public Administration, 11 Prechistenskaya naberezhnaya, 119034 Moscow, Russian Federation; E-mail: safonkina-ea@ranepa.ru

Andrei Sakharov - Researcher, Centre for International Institutions Research, Russian Presidential Academy of National Economy and Public Administration; 11 Prechistenskaya naberezhnaya, 119034 Moscow, Russian Federation; E-mail: sakharov-ag@ranepa.ru

Andrey Shelepov - Researcher, Centre for International Institutions Research, Russian Presidential Academy of National Economy and Public Administration; 11 Prechistenskaya naberezhnaya, 119034 Moscow, Russian Federation; E-mail: shelepov-av@ranepa.ru

Turkey held the presidency of the G20 (Group of 20) from December 2014 to November 2015. During this period geopolitical tensions started to spread beyond the borders of the regions involved. It directly affected Turkey which had to tackle with the refugees inflows and the terrorist attacks consequences. The situation was exacerbated by the additional general election and a slowing economy.

Turkey defined three priorities for its presidency: inclusiveness, implementation and investment for growth. To combat inequality and ensure inclusive growth, it aimed to address the issues of small and medium-sized enterprises, such as access to finance, skills and global value chains, employment for youth and women, and support to the development of low-income countries. Inclusiveness was also explicit in G20 engagement with social partners. Implementation was emphasized, particularly related to the imperative to deliver on the G20 members' commitments regarding growth strategies made at the 2014 Brisbane Summit.

This article assesses the G20's performance under the Turkey presidency within a functional paradigm focusing on the three main objectives of plurilateral summitry institutions: strengthening capacity for political leadership to launch new ideas and overcome deadlocks, reconciling domestic and international

${ }^{1}$ The publication was prepared in the framework of the research project "Evaluating G20 and BRICS Effectiveness for the Russian Federation Priorities" implemented by the RANEPA Center for International Institutions Research. The editorial board received the article in November 2016. 
pressures, and consolidating collective management. To attain those objectives, institutions are expected to demonstrate leadership, solidarity, sustainability, acceptability, consistency and continuity. Efficiency is perceived as G20 performance on a combination of the criteria. Given the G20's ultimate mission to achieve strong, sustainable, balanced and inclusive growth, all the issues on Turkey's G20 agenda were grouped according to these four growth pillars.

G20 performance on each of the issue areas was assessed on six criteria using a three-point scale: high (1), medium (0) and low (-1) degree of performance. The overall assessment of G20 performance efficiency was estimated as the total of the average scores in each issue area divided by 11 (the number of policy areas on the agenda). Recognizing that implementation is crucial to G20 legitimacy, leadership and solidarity, Turkey made it one of its presidency's priorities. Thus, the quality of accountability and level of compliance are considered within each policy area. The quality of engagement is included in the assessment of the acceptability of G20 decisions within respective policy areas, with the format of G20 engagement with outreach, including social partners, international institutions and non-G20 countries, explored in a separate section.

The analysis showed that the G20 under the Turkish presidency attained a high level of consistency and continuity in all issues, ensuring the consistency of decisions across policy areas and their compatibility with the agenda of previous presidencies and 620 core agenda. Sustainability and acceptability were also quite high, as the G20 ensured the longevity of collectively produced solutions and got the endorsement of the decisions by other governments, international institutions and social partners. However, the Turkish presidency lacked leadership, showing not enough capacity to exercise political authority and overcome deadlocks, which could be partly explained by the challenges of the internal situation in Turkey. The lowest level was registered for solidarity as some G20 members did not fully commit to certain decisions and parts of the programs and documents were perceived as voluntary. The G20 displayed many of the features of plurilateral summitry institutions in all the areas under the goal of balanced growth and almost all with regard to the goal of inclusive growth. On sustainable growth, the performance was mixed on both energy and climate change. With a relatively high average for strong growth, the outcomes by issue were uneven: relatively high on macroeconomic cooperation and investment, and rather low on trade. The trade agenda was the only one with negative scores for leadership and solidarity, proving to be one of the most persistent challenges for the G20.

Key words: G20; Turkey; plurilateral summit institutions; summit performance; macroeconomic cooperation; investment; IFI reform; international trade; energy; climate change and environment; international tax; anti-corruption; international financial system reform; employment; development cooperation

For citation: Larionova M., Rakhmangulov M., Safonkina E., Shelepov A., Sakharov A. (2017) G20 Priorities and Decisions in the Framework of the Turkish Presidency: Implementation, Inclusiveness, and Investment for Strong, Sustainable and Balanced Growth. International Organisations Research Journal, vol. 12, no 1, pp. 148-173 (in Russian and English). DOI: 10.17323/1996-7845-2017-01-148. 
Turkey took over the stewardship of the G20 from Australia at a time of "weaker-thanexpected global activity." The IMF growth forecast for the world economy was revised downward to 3.3 percent for 2014, 0.4 percentage points lower than the April 2014 World Economic Outlook (WEO), thereby alerting governments to an increase in downside risks [IMF, 2014, p. XV]. Despite the G20 Brisbane Action Plan to implement members' growth strategies and lift the G20's collective GDP by 2.1 percent by 2018 (which was above the trajectory implied by policies at the time of the St Petersburg Summit) and also to boost the GDP of non-G20 economies by over 0.5 percent [G20 2014], the IMF global growth projection for 2015 was lowered to 3.8 percent [IMF, 2014, p. XV].

Geopolitical tensions started to spread beyond the borders of the regions involved. Economic sanctions continued to impact foreign investment, domestic production, and business and consumer confidence in Russia. Weak domestic demand contained growth in Latin America, China and Japan. Migration flows expanded into the EU, affecting mostly the Mediterranean countries at that point. In most G20 members, the economic slump led to increased inequality.

Turkey, the G20 Chair, was going through a difficult period, with a slowing economy, two elections in June and November 2015, revived confrontations between the ruling Justice and Development party (AKP) and the outlawed Kurdish Nationalist PKK (Kurdistan Workers' party), two million refugees in the country, frustrated efforts to secure its borders and tackle terrorism and the fear of terror after the bombings in Ankara and Suruç [Avatkov, Kochkin, 2016; The Guardian, 2015]. At this time, the country took over the responsibility for steering the G20, with a commitment to address the critical challenge the G20 was set up for: "ensuring inclusive and robust growth through collective action" [Turkish G20 Presidency, 2015a].

The Turkish presidency defined three priorities: Inclusiveness, Implementation, and Investment for Growth. To combat inequality and ensure inclusive growth, it aimed to address the problems facing SMEs, such as access to finance, skills, and GVCs; to boost the employment of young people and women; and to provide support for the development of LICs. Inclusiveness was also explicit in the G20's engagement with social partners. A strong emphasis on implementation was in particular related to the imperative for delivering on the G20 members' Brisbane commitments, in particular the growth strategies. Given the role of investment as a driver of growth, the presidency proposed that the members develop and adopt ambitious investment strategies with a focus on infrastructure investment and PPP.

The intense work which went into the summit preparations during the course of a turbulent year, culminated in a leaders' meeting that was overshadowed by a terrorist attack, the G20 Statement on the Fight Against Terrorism, the Leaders' Communique, the G20 Action plan, 21 documents appended to the Communique, 54 supporting documents prepared by international institutions and experts, and 113 commitments.

\section{Methodology}

This article assesses the outcomes of the G20's performance under the Turkish presidency within a functional paradigm, focusing on the performance of the G20 on the three main 
objectives of plurilateral summitry institutions: strengthening capacity for politicalleadership to launch new ideas and overcome deadlocks; reconciling domestic and international pressures; and consolidating collective management. ${ }^{2}$ To attain these objectives, the summit institutions are expected to demonstrate leadership (the capacity to exercise political authority and overcome deadlocks), solidarity (the degree of members' commitments to decisions), sustainability (longevity of the collectively produced solution), acceptability (endorsement of the decisions by the other governments, international institutions and nonstate actors), consistency (compatibility of decisions across policy areas) and continuity (compatibility of decisions with the agenda of previous presidencies). It is very rare for any of the summitry institutions ${ }^{3}$ to display a combination of all these characteristics to the full degree. These features have been used as criteria for assessing the G7/G8 summit results by Nicolas Bayne [Bayne, 2005].

Our methodology draws on Bayne's analytical paradigm with full recognition of the differences in the two institutions' missions, membership and agendas, on one hand, and their similarities as informal global summit institutions, on the other. It is fine-tuned to reflect the difference in the object of assessment: G20 performance steered by the country holding the presidency, versus a G7/G8 summit. Stemming from the above characteristics, six criteria are identified and applied for assessing the G20's performance under the Turkish presidency: leadership; solidarity; sustainability (future-oriented and long-term character of commitments); acceptability (including engagement with international institutions, invited countries and social partners, with an understanding that there is a high correlation between the quality of engagement ${ }^{4}$ and the acceptability of the G20 decisions), consistency (compatibility of decisions across policy areas) and continuity (building on, reinforcing or taking into consideration the legacy of the previous summits). Efficiency is perceived as the G20's performance on a combination of the criteria.

Given the G20's ultimate mission of achieving strong, sustainable, balanced and inclusive growth, for this study all G20 Turkey agenda issues were grouped within these four growth pillars. With the caveat that the four pillars can be attained through a combination of G20 actions in related policy areas, the grouping was made with consideration of the issues' comparative relevance to the pillars. The implementation of G20 decisions, currently totaling 1,762 commitments across the 10 summits, poses a challenge. Recognizing that implementation is crucial to the G20's legitimacy, leadership and solidarity, Turkey made it one of the presidency's priorities. Thus, quality of accountability and level of compliance

${ }^{2}$ The summits' objectives were formulated by Nicolas Bayne and used to assess G7/G8 performance in [Bayne, 2005].

${ }^{3}$ Informal summitry institutions are defined as international institutions with limited membership, relatively low bureaucracy, consensual decisions, and reliance on open, flexible and voluntary approaches. Regular meetings of the heads of states and governments who engage in policy coordination on a wide range of international, regional and domestic politics stand at the pinnacle of such international arrangements, which involve many actors operating according to established procedures on two levels: domestic and international. Commitments contained in the collectively agreed documents are not legally-binding but their implementation is stimulated by peer pressure. Among such bodies engaged in global and regional governance are the G7/G8, G20, BRICS, and APEC.

${ }^{4}$ Quality of engagement is understood as both intensity and capability of the G20 to reflect messages from the outreach partners in their documents. 
are considered within each of the policy areas. Though G20 engagement with outreach formats, including social partners, international institutions and non-G20 countries is explored in a separate section, quality of engagement is taken into account in assessing G20 decisions' acceptability within respective policy areas.

The G20's performance on each of the issue areas was assessed on the six criteria on a three-point scale: high (a score of 1 ), medium (a score of 0 ) and low (a score of -1 ). The overall assessment of the G20's performance was estimated as the sum total of the average scores in each of the issue areas, divided by 11 (the number of policy areas on the agenda).

\section{Strong growth}

\section{Macroeconomic cooperation}

The G20's strong focus on macroeconomic cooperation during the Turkish presidency was aimed at facilitating a global recovery and lifting the growth potential of the member economies. Thus, the presidency committed to ensure that G20 members' "actions complement each other for a strong, sustainable and balanced growth" and "try to reach an appropriate fiscal and monetary policy mix in addition to the proper implementation" of structural reforms [Turkish G20 Presidency, 2015a].

The work on macroeconomic issues was carried out on a financial track. G20 finance ministers and central bank governors convened four times in 2015, reiterating the traditional G20 macroeconomic commitments on flexible implementation of fiscal policies, putting debt as a share of GDP on a sustainable path, promoting global rebalancing, carefully calibrating and clearly communicating their actions, trying to minimize negative spillovers, and keeping exchange rates flexible and resisting financial protectionism. Following the pledge made in Brisbane to lift the collective GDP of the G20 by an additional two percent by 2018, finance ministers and central bank governors prioritized sound and coordinated macroeconomic policies to ensure strong, sustainable and balanced growth, while also trying to make it inclusive.

Despite some progress in implementing the comprehensive growth strategies endorsed at the Brisbane summit, G20 countries complied with about a half of their multi-year commitments. This implementation level allowed only one third of the collective growth target to be achieved. While acknowledging that more needs to be done to lift their GDP by an additional two percent, the ministers agreed to continue monitoring the implementation of commitments through a "robust framework" [G20, 2015a], review, and an adjustment of growth strategies to ensure their consistency with the collective growth ambition [G20, 2015b].

The work on two new priorities was completed by the time of the Antalya summit. The leaders endorsed the Accountability Assessment Report with an update on individual and collective progress on previous commitments and, based on input from the G20 finance ministers, adopted the Antalya Action Plan comprising the adjusted comprehensive growth strategies and implementation schedules for the key points [G20, 2015c]. Significantly, compared with the Brisbane documents, individual growth strategies and Action Plan agreed in Antalya contain a number of commitments aimed at achieving inclusive growth, for instance through policies to address inequality [G20, 2015d]. 
The G20's compliance in the macroeconomic sphere was assessed by monitoring its commitment on flexible implementation of fiscal policies to take into account near-term economic conditions. The average level of compliance was slightly higher (80\%) than the Antalya summit average (77\%), but eight members showed only partial compliance.

Thus, in the macroeconomic sphere the Turkish presidency maintained the G20 members' long-lasting cooperation for strong, sustainable and balanced growth. At the same time, it consolidated efforts to achieve the additional two-percent growth target announced in Brisbane, by monitoring the implementation of individual growth strategies through an effective accountability framework; and also by adjusting the strategies in line with the evolving economic conditions, and improving their inclusiveness. Overall, in the area of macroeconomic cooperation and coordination, the G20 demonstrated continuity and consistency with other policy areas, such as investment, financial regulation, and trade. At the same time, additional solidarity and sustainability are needed to agree and fully implement commitments that could help to achieve the additional two-percent growth target (Table 1).

Table 1: Macroeconomic Cooperation Performance Assessment

\begin{tabular}{|l|c|}
\hline \multicolumn{1}{|c|}{ Criterion } & Score \\
\hline Leadership & 1 \\
\hline Solidarity & 0 \\
\hline Sustainability & 0 \\
\hline Acceptability & 1 \\
\hline Consistency & 1 \\
\hline Continuity & 1 \\
\hline
\end{tabular}

Source: compiled by the authors.

\section{Investment}

Boosting investment was one of the priorities of the Turkish G20 presidency. The primary outcome was the adoption of country-specific investment strategies by the G20 members, mandated by the G20 Finance Ministers and Central Bank Governors at their meeting in February 2015. These strategies contained concrete policies and plans by national governments aimed at improving investment environments in their respective jurisdictions. The OECD supported this work by providing first a preliminary review, and later qualitative and quantitative assessments of the strategies [G20, OECD, 2015].

In order to "improve our investment preparation, prioritization and execution processes" the G20 worked to develop guidelines for and highlight best practices of publicprivate-partnership (PPP) models. The Finance Ministers and Central Bank Governors asked the World Bank Group (WBG) to report on current international practices to promote PPP transparency, and develop a "voluntary toolkit for increasing public awareness and understanding of PPP projects" [G20, 2015e].The WBG released a series of PPP Guidelines (Overview Note for WBG Infrastructure Deliverables, Infrastructure Prioritization Toolkit, Framework for Disclosure for PPP Projects, Partnering to Build 
a Better World - MDBs Common Approaches on Supporting Infrastructure Development, Report on Recommended PPP Contractual Provisions) for the September 2015 meeting of the G20 Finance Ministers and Central Bank Governors.

Another element of the 2015 G20 investment agenda, aimed at promoting inclusiveness, was support for SMEs' greater involvement in investment activities, with an emphasis on long-term financing. The leaders welcomed the Joint Action Plan on SME Financing, the G20/OECD High-Level Principles on SME Financing, and the creation of the World SME Forum, a new private sector-led initiative launched at the September 2015 B20/G20 meeting in Ankara. The Forum is envisaged as "a global body to facilitate the contributions of SMEs to growth and employment" [Ibid.].

To improve the business environment and support private investment, the G20 endorsed the G20/OECD Principles of Corporate Governance [G20, 2015c].

The OECD and World Bank were actively involved in the G20's work on investment at all stages. Aside from the reports mentioned above, and the OECD's participation in the G20 investment strategies' evaluation, these international institutions presented a large body of supporting documents for ministers and leaders, including the Report on StockTaking of Selected Policy Indicators on the Enabling Environment for Infrastructure Investment, the Report on Risk and Return Characteristics of Infrastructure Investment in Low Income Countries, and the "Effective Approaches to Support Implementation of the G20/OECD High-Level Principles on Long Term Financing by Institutional Investors" document [Ibid.]. The active involvement of international bodies testifies to the G20's reliance on their expertise on the one hand, and on the other, the forum's inclination to increase the legitimacy and acceptability of its decisions.

Overall, in 2015 the Turkish G20 presidency managed to harness international support to promote important decisions aimed at facilitating private investment flows and enhancing the global business environment by promoting coherence and predictability in members states' national investment policies (Table 2).

Table 2: Investment Performance Assessment

\begin{tabular}{|l|c|}
\hline \multicolumn{1}{|c|}{ Criterion } & Score \\
\hline Leadership & 1 \\
\hline Solidarity & 1 \\
\hline Sustainability & 1 \\
\hline Acceptability & 1 \\
\hline Consistency & 1 \\
\hline Continuity & 1 \\
\hline
\end{tabular}

Source: compiled by the authors.

\section{Reforming international financial institutions}

The Turkish presidency pledged to put a continued emphasis on the ratification of the 2010 IMF Quota and Governance Reform in 2015, as completing the IMF reform would "help the Fund maintain its legitimacy and effectiveness" [Turkish G20 Presidency, 2015a]. 
It was agreed that in case of failure, the G20 should start discussions on "alternative ways to enhance the governance of the Fund, with a view to preserve the spirit of the 2010 Reform Package." Other priorities within the international financial architecture agenda included strengthening IMF surveillance in the post-crisis world, addressing concerns related to the stigma associated with the Fund's financing, and ensuring adequacy of the global financial safety net [Turkish G20 Presidency, 2015a].

However, the IMF reforms were not completed during the Turkish presidency due to the United States' inability to ratify the reform package. In the Antalya summit communique the G20 leaders expressed deep disappointment with the continued delay in implementing the IMF reforms, stating that these reforms remain the highest priority for the IMF, and urged the United States to ratify them as soon as possible. They also asked the IMF to prepare an interim solution that can "meaningfully converge quota shares as soon as and to the extent possible to the levels agreed under the 14th General Review of Quotas." This controversial process was completed in December 2015 when the U.S. Congress adopted legislation authorizing the 2010 Quota and Governance Reforms. ${ }^{5}$

At the Antalya Summit the G20 also reaffirmed that the composition of the Special Drawing Rights (SDR) basket should continue to reflect the role of currencies in the global trading and financial system, and look ahead to the completion of a review of the method of valuation of the SDR [G20, 2015c]. On the last day of the Turkish presidency (30 November 2015), the IMF Executive Board approved the Chinese yuan as a freely usable currency and included it in the SDR basket as a fifth currency with a share of $10.92 \% .^{6}$

The level of the G20's compliance with the commitment to maintaining a strong, quota-based and adequately resourced IMF was relatively high (93\%), but three countries, including Turkey, showed only partial compliance.

Thus, the G20 under the presidency of Turkey was not able to complete the IFIs reforms agreed earlier, and to make all members comply with their relative commitments, demonstrating a moderate level of leadership and solidarity (Table 3).

Table 3: Reforming IFIs Performance Assessment

\begin{tabular}{|l|c|}
\hline \multicolumn{1}{|c|}{ Criterion } & Score \\
\hline Leadership & 0 \\
\hline Solidarity & 0 \\
\hline Sustainability & 1 \\
\hline Acceptability & 1 \\
\hline Consistency & 1 \\
\hline Continuity & 1 \\
\hline
\end{tabular}

Source: compiled by the authors.

${ }^{5}$ IMF Managing Director Christine Lagarde Welcomes U.S. Congressional Approval of the 2010 Quota and Governance Reforms, 18 December, 2015. Available at: http://www.imf.org/external/np/sec/pr/2015/pr15573.htm (accessed 20 February 2017).

${ }^{6}$ Press Release: IMF Executive Board Completes the 2015 Review of SDR Valuation, 1 December, 2015. Available at: http://www.imf.org/en/news/articles/2015/09/14/01/49/pr15543 (accessed 20 February 2017). 


\section{Trade}

International trade has been one of the key items on the G20 agenda since its inception as the leaders' forum. In 2015 the Turkish G20 presidency faced a traditional assortment of trade-related issues, from stalling trade growth to rising protectionism affecting the world economy, and responded with a number of set-piece statements, calls, and commitments.

On 6 October 2015, the third meeting of the G20 trade ministers took place in Istanbul. The Turkish presidency invited the representatives of several non-G20 countries: Azerbaijan, the Netherlands, Kenya (as the host of tenth WTO Ministerial Conference), Malaysia (as the 2015 Chair of ASEAN), Senegal (representing NEPAD), Singapore, and Spain, as well as international institutions: the OECD, IMF, World Bank and WTO, to take part in the meeting. In the resulting document, the Chairman's Summary, the ministers expressed their concern over the unsteady recovery of global trade growth after the 2008 financial crisis, and made a range of commitments across the established G20 trade agenda.

The overarching priority designated by the ministers was to counter cyclical and structural factors behind the global trade slowdown through a set of "deeper and broader policies." The ministers confirmed their determination to carry through on the traderelated actions from the Comprehensive Growth Strategies. As recognized by the G20 trade ministers, in addition to their original aim of boosting global growth by an additional 2.1 percent by 2018 , these strategies could also resolve some of the issues affecting world trade.

The set of issues covered by the ministers in Istanbul remained virtually unaltered compared to the traditional G20 trade agenda. While bolstering the institution's continuity, such an approach showed the Turkish presidency's lack of leadership and its inbility to ensure consensus to promote new, more ambitious trade agenda items and concrete decisions.

The most symbolic example of the G20's inability to promote any real change in the global trade outlook is its traditional standstill and rollback commitment. As in previous years, the Chairman's Summary from the Trade Ministers' Meeting included the confirmation of a pledge to abstain from introducing new protectionist measures and to roll back the existing ones, while the Leaders' Communique additionally contained a call for the WTO, OECD and UNCTAD to continue their joint monitoring exercise and reporting on restrictive measures to trade and investment. However, despite this arrangement being in place since 2008, there has been no consistent slowdown in the rate of introduction of new restrictive measures by the G20 members. The July 2016 WTO report on traderelated developments registered an intensification of protectionism, with 22 new measures introduced per month on average (October 2015 - May 2016). Furthermore, the stockpile of protectionist measures increased by 11 percent compared to the previous monitoring period, and was estimated at $2,127 .^{7}$ So far, the monitoring exercise, which itself reveals the G20's failure in fighting protectionism, remains the only practical result of this commitment.

Other trade-related issues discussed during the Turkish G20 presidency included the promotion of global value chains' (GVCs) inclusiveness and SMEs participation in them,

${ }^{7}$ Report urges WTO members to resist protectionism and "get trade moving again," WTO, 25 July, 2016. Available at: https://www.wto.org/english/news_e/news16_e/trdev_22jul16_e.htm (accessed 20 February 2017). 
ensuring the compatibility of regional trade agreements (RTAs) with multilateral trading system requirements, and expectations for the upcoming WTO Ministerial Conference in Nairobi.

The G20 trade ministers, later supported by the national leaders, recognized "the crucial role of GVC participation for economic development and growth," and acknowledged the importance of providing SMEs with means and opportunities to engage in GVCs and take full advantage of such engagement, regardless of the level of host counties' economic development. In this regard the G20 agreed to address economic constraints and reduce the burden affecting SMEs. The G20 once again called for speedy ratification and implementation of the Trade Facilitation Agreement.

The steady expansion of regional and supra-regional trade agreements in a number of involved economies, their comparative share in world trade, and their political significance necessitated a thorough discussion and palpable response from the forum of the world's leading economies on what may be perceived as a threat to the cohesion of the global trading regime. The WTO prepared the "Regional Trade Agreements and the Multilateral Trading System" discussion paper for the G20 to promote a better understanding of the interplay between RTAs and WTO provisions. ${ }^{8}$

The G20, however, confined itself to confirming its position set out in the 2013 "Advancing Transparency in Regional Trade Agreements" document [G20, 2013] - that the G20 would continue to ensure that "bilateral, regional and plurilateral trade agreements complement one another, are transparent and contribute to a stronger multilateral trading system under the WTO rules." The absence of concrete decisions in this area can also be attributed to the lack ofleadership and inability to consolidate G20 members' solidarity under the Turkish presidency. Moreover, the level of compliance with the traditional commitment on anti-protectionism was one of the lowest among all Antalya Summit commitments assessed (65\%). Only six G20 members fully complied with this commitment.

The consistent engagement of the G20 with international institutions such as the WTO, OECD and UNCTAD, providing expertise and monitoring capacities, the guest countries bolstering the institution's legitimacy, and social outreach partners, specifically the B20 which was commended by the trade ministers for providing useful recommendations "which identified important policy options for us in boosting trade as our representatives in the field," demonstrated the forum's efforts to increase the acceptability of its decisions among the wider public.

Despite the absence of breakthrough decisions and commitments, the 2015 trade agenda can boast a high degree of continuity and consistency - its items being strongly intertwined with the other elements of the overall G20 drive towards strong, sustainable, balanced and inclusive growth, specifically in terms of the economic and developmental impacts of international trade (Table 4).

${ }^{8}$ Regional Trade Agreements and the Multilateral Trading System, WTO, 21 September 2015. Available at: http://g20.org.tr/wp-content/uploads/2015/11/8.G20-Discussion-Paper_RTAs-andMTS.pdf (accessed 20 February 2017).

${ }^{9}$ Chairman's Summary Meeting of G20 Trade Ministers, G20, 6 October 2015. Available at: http://www.g20.utoronto.ca/2015/151006-trade.html (accessed 20 February 2017). 
Table 4: Trade Performance Assessment

\begin{tabular}{|l|c|}
\hline \multicolumn{1}{|c|}{ Criterion } & Score \\
\hline Leadership & -1 \\
\hline Solidarity & -1 \\
\hline Sustainability & 0 \\
\hline Acceptability & 1 \\
\hline Consistency & 1 \\
\hline Continuity & 1 \\
\hline
\end{tabular}

Source: compiled by the authors.

\section{Sustainable growth}

\section{Energy}

The 2015 G20 energy agenda built on the momentum gained during the 2014 Australian presidency and produced important institutional outcomes and concrete commitments.

The first ever meeting of the G20 energy ministers, mandated by the leaders at the 2014 Brisbane summit, took place on 2 October 2015 in Istanbul.

The key decision of the meeting was the adoption of the "G20 Energy Access Action Plan: Voluntary Collaboration on Energy Access," later endorsed by the leaders in Antalya. ${ }^{10}$ The Action Plan represents a multi-phased G20 initiative aimed at complementing existing regional and global arrangements in the energy field. The first phase, presented by the G20 in 2015, was devoted to improving electricity access in Sub-Saharan Africa. Listing key regional challenges and ways to overcome them, the plan focused on building up support for national governments' actions in developing the regulatory environment, and attracting financing, technology, expertize, etc. In Antalya the leaders pledged to "cooperate and collaborate with African countries and relevant regional and international organizations on policy and regulatory environments, technological development and deployment, investment and finance, capacity building, regional integration and cooperation, taking into consideration national needs and contexts" [G20, 2015c].

The G20 member states' relevant good practices were annexed to the G20 Energy Access Action Plan. The good practices were submitted by 14 members of the G20, Singapore, and the African Union Commission, for the purpose of sharing information and experience on ensuring access to energy. Surprisingly, several developed G20 members were not engaged in this voluntary but important process (Canada, Germany, United States, the European Union). Indonesia and Saudi Arabia did not prepare their good practices either, and the document of China was quite brief, consisting of only three paragraphs.

The second document, adopted by the energy ministers and commended by the leaders, was the G20 Toolkit of Voluntary Options for Renewable Energy Deployment [G20, 2015h].

${ }^{10}$ G20 Energy Access Action Plan: Voluntary Collaboration on Energy Access, G20 16 November 2015. Available at: http://www.g20.utoronto.ca/2015/G20-Energy-Access-ActionPlan.pdf (accessed 20 February 2017). 
This toolkit elaborated on several of the commitments on renewable energy promotion from the G20 principles on Energy Collaboration, endorsed by the G20 leaders in Brisbane. The document proposed five principle areas of collaboration: analysis of renewable technology costs, cost reduction potential, and good-practice exchanges; good-practice exchanges on enabling a national policy framework design and power systems integration of higher shares of variable renewables; development of a renewable-energy-specific risk mitigation facility; assessment of country renewable energy technology potential and development of roadmaps; and deployment of modern bioenergy.

The G20 energy ministers and leaders also discussed cooperation among international energy institutions, energy market transparency, energy security, fossil fuel subsidies, energy efficiency, renewable energy sources, innovative energy technology, and, finally, the environmental implications of energy policy. Notable commitments across these issue areas included: the traditional G20 pledge to phase out inefficient fossil fuel subsidies encouraging wasteful consumption, as well as a commitment to promote transparent, competitive and well-functioning energy markets.

The national leaders mandated their Energy Ministers to continue their collaboration and report back in 2016 on progress in implementing the G20 Principles on Energy Collaboration. Overall, in 2015 the G20 demonstrated leadership to continue the constructive course set during the previous year, and showing resolve to launch important collective initiatives to help resolve energy access issues in the region where they are the most acute. The 2015 energy agenda demonstrated a high degree of consistency, providing a link between energy-related issues and a wider development agenda. The institutionalization of Energy Ministers' dialogue should help actualize the G20 energy agenda, with its focus on development and renewables bringing it closer in line with other areas of the forum's work.

However, the low level of G20 compliance with the energy commitment (33\%) indicates insufficient solidarity. The commitment to rationalise and phase out inefficient fossil fuel subsidies was traditionally poorly complied with by the G20. After the Antalya Summit, only Argentina, India and the United States fully complied with this commitment and 10 members failed to comply (Table 5).

Table 5: Energy Performance Assessment

\begin{tabular}{|l|c|}
\hline \multicolumn{1}{|c|}{ Criterion } & Score \\
\hline Leadership & 1 \\
\hline Solidarity & -1 \\
\hline Sustainability & 1 \\
\hline Acceptability & 0 \\
\hline Consistency & 1 \\
\hline Continuity & 1 \\
\hline
\end{tabular}

Source: compiled by the authors. 


\section{Climate Change and Environment}

In 2015 as in most previous years, climate change was closely intertwined with energy issues on the G20 agenda. The environment was also discussed at the agriculture ministers' meeting on 8 May 2015 in Istanbul.

Agriculture ministers stressed the importance of promoting sustainable agricultural practices in order to increase the effectiveness of natural resource consumption, build up resilience, and help address climate change, while recognizing the challenge that the changing environment presents for food security. The G20 Action Plan on Food Security and Sustainable Food Systems, released as an annex to the Summit's Communiqué, also underlined the need to ensure the environmental sustainability of food systems around the world [G20, 2015h].

During their first meeting, held on 2 October 2015 in Istanbul, the G20 energy ministers discussed several important climate-related issues, such as the environmental impact of energy policy, energy efficiency and sustainability, renewables, and clean energy technology, thereby securing an important link between the energy and climate change agendas, which had traditionally been a characteristic of the G20's work in these areas. The ministers acknowledged the importance of developing sustainable and clean innovative energy technology, recognizing that apart from boosting economic growth and employment they can also "provide environmental benefits." Energy ministers pledged to take "strong and effective action to tackle climate change" in 2015 through improving energy efficiency and scaling up investments in clean energy, expressing support for the work of the UNFCCC as the primary international body for climate change negotiations [G20, 2015f].

At the Antalya summit, the G20 leaders reaffirmed the goal of limiting the increase in global average temperatures to $2^{\circ} \mathrm{C}$ above pre-industrial levels, stated in the Lima Call for Action, and resolved to adopt a legally binding protocol under the UNFCCC to that end. The leaders also committed to implement their Intended Nationally Determined Contributions (INDCs) to the UNFCCC and to cooperate towards a successful outcome of the COP21 [G20, 2015c].

The year 2015 was marked by an even closer integration of climate change and environmental issues with energy and food security elements of the agenda, increasing the consistency of the G20's cooperation across these issue areas. However, no specific climaterelated documents or new commitments were adopted by the leaders, which negatively affected the leadership score of the 2015 Turkish presidency (Table 6).

Table 6: Climate Change and Environment Performance Assessment

\begin{tabular}{|l|c|}
\hline \multicolumn{1}{|c|}{ Criterion } & Score \\
\hline Leadership & 0 \\
\hline Solidarity & 1 \\
\hline Sustainability & 1 \\
\hline Acceptability & 0 \\
\hline Consistency & 1 \\
\hline Continuity & 1 \\
\hline
\end{tabular}

Source: compiled by the authors. 


\section{Balanced growth}

\section{International taxation}

Building on the G20's leadership in addressing base erosion and profit shifting, fighting tax evasion and promoting tax transparency, the Turkish G20 presidency focused its tax agenda on three related areas: implementation and monitoring of the Base Erosion and Profit Shifting (BEPS) Action Plan; ensuring tax transparency; and increasing the engagement of developing countries in the international tax agenda. Of these three areas, clear priority was given to BEPS, as the Turkish presidency decided to focus on "monitoring the implementation of the 2014 deliverables of the Base Erosion and Profit Shifting (BEPS) Project" and expressed a commitment to "work to ensure a smooth transition to the 2015 deliverables of the BEPS project to secure progress in this field" [Turkish G20 Presidency, 2015b].

In the tax-related part of the Antalya communique, the G20 leaders highlighted progress in the three main areas of the forum's work on taxes. Success on two out of three tax priorities was limited. In particular, the leaders reaffirmed the previous G20 commitments on tax information exchange on-request and automatic exchange of information by 2017 or 2018, and expressed their support for efforts aimed at strengthening developing economies' engagement in the international tax agenda [G20, 2015c].

At the same time, the G20 demonstrated strong leadership in the work on BEPS. During the Turkish presidency, the G20 and OECD finalized the BEPS Package and launched a new phase of their joint BEPS project aimed at monitoring the implementation of the agreed measures. The finance ministers, and later the leaders, called "on the OECD to develop an inclusive framework by early 2016 with the involvement of interested nonG20 countries and jurisdictions which commit to implement the BEPS project, including developing economies, on an equal footing" [G20, 2015c]. The commitment to further incorporate developing countries' perspectives into the G20 tax agenda and facilitate bilateral and multilateral cooperation between tax authorities, is in line with the presidency's overall focus on inclusiveness.

The level of compliance with two tax-related commitments was high as most G20 members fully complied with strengthening developing economies' engagement in the international tax agenda (93\%) and ensuring information exchange on request, as well as automatic exchange of tax information by 2017 or the end of 2018 (89\%).

The Turkish presidency further consolidated G20 cooperation on global tax issues. Although no specific new commitments to address any tax issues except BEPS were made, during the Turkish presidency the G20 demonstrated leadership in setting directions for further OECD work on taxes; solidarity among members on the necessity and urgency of addressing tax base erosion; continuity and sustainability of the decisions made; support among non-G20 countries actively engaged in its work on the global tax agenda; and consistency with other policy areas such as crime and corruption reflected, for instance, in the adoption of implementation plans on beneficial ownership transparency (see below in the next part of the article) (Table 7). 
Table 7: International Taxation Performance Assessment

\begin{tabular}{|l|c|}
\hline \multicolumn{1}{|c|}{ Criterion } & Score \\
\hline Leadership & 1 \\
\hline Solidarity & 1 \\
\hline Sustainability & 1 \\
\hline Acceptability & 1 \\
\hline Consistency & 1 \\
\hline Continuity & 1 \\
\hline
\end{tabular}

Source: compiled by the authors.

\section{Anti-corruption}

In the area of fighting corruption, the G20 under the Turkish presidency continued to implement and monitor the implementation of the 2015-2016 G20 Anti-Corruption Action Plan adopted in 2014. The Turkish presidency also committed to work closely with the relevant international organizations and give particular importance to the fight against corruption in the public and private sectors. One specific topic - transparency in government-business relations - was emphasized in the document on the Turkish presidency priorities.

The Anti-Corruption Working Group (ACWG) prepared the Accountability Report for 2015, although it was not published on the Turkish presidency website or in other sources.

At the Antalya Summit the G20 leaders endorsed the G20 High-Level Principles on Integrity and Transparency in the Private Sector. The document consists of 17 principles which aim to help the companies comply with global standards on ethics and anti-corruption [G20, 2015i].

To ensure the integrity and transparency of the public sector, the G20 endorsed the G20 Anti-Corruption Open Data Principles [G20, 2015j] and the G20 Principles for Promoting Integrity in Public Procurement.

An important achievement in the anti-corruption area was the publication of individual implementation plans on beneficial ownership transparency. However, not all G20 members adopted their implementation plans: the plans of Brazil, Saudi Arabia, and European Union were not published. ${ }^{11}$ The absence of an EU plan can be explained by the specific nature of the EU as a supranational entity, while the measures on beneficial ownership should be mainly taken at the national level [G20, 20151]. At the same time, a detailed plan on Spain (a country permanently invited to G20 summits) was published together with other G20 members. The plans differ substantially in terms of volume, nature and structure. Argentina's plan consists of 33 pages, while the plan of France contains only one page. The document on India is called a "country report" and mainly describes the measures already taken in the area of beneficial ownership. It is mentioned in the Argentina's plan

${ }^{11}$ Written Implementation Plan on Beneficial Ownership, G20. Available at: http://g20.org. tr/wp-content/uploads/2015/11/Written-Implementation-Plan-on-Beneficial-Ownership.pdf (accessed 20 February 2017). 
as a "draft as of 7 September 2015," while the Russian document is the National Plan on Countering Tax Evasion and Concealing Beneficial Owners of Companies approved by the Government of Russia on 30 April 2014 [G20, 2015m]. It should be noted that the original Russian national plan published in Russia provides for the implementation of all actions before December 2015.

The level of G20 performance on anti-corruption was high on all criteria. Turkish Presidency demonstrated leadership having included new issues into the agenda (anticorruption and standards on ethics in private sector), solidarity through individual action-plans and sustainability by implementing the decisions and relevant action-plan adopted during previous presidencies. Acceptability was ensured through cooperation with international organizations and partners, business in particular, and continuity through connection with other priorities (financial regulation and SME development) (Table 8).

Table 8: Anti-Corruption Performance Assessment

\begin{tabular}{|l|c|}
\hline \multicolumn{1}{|c|}{ Criterion } & Score \\
\hline Leadership & 1 \\
\hline Solidarity & 1 \\
\hline Sustainability & 1 \\
\hline Acceptability & 1 \\
\hline Consistency & 1 \\
\hline Continuity & 1 \\
\hline
\end{tabular}

Source: compiled by the authors.

\section{Global financial system reform}

Since the launch of the forum, the G20 members have agreed a broad range of policy reforms to strengthen financial stability. The core elements of the G20 financial regulatory agenda are close to completion. Building on this, the Turkish presidency decided to focus on finalizing the remaining reforms of the global regulatory framework, monitoring full and timely implementation, and analyzing the effects of the reforms, in order to address unintended consequences.

During the Turkish presidency, the G20 made substantial progress across all three areas. On the G20's request, the Financial Stability Board (FSB) and the International Association of Insurance Supervisors (IAIS) developed the common international standard on total loss-absorbing capacity (TLAC) for global systemically important banks [FSB, 2015] and higher loss absorbency (HLA) requirements for global systemically important insurers [IAIS, 2015], respectively. At the Antalya summit, the leaders endorsed the new standards and agreed to continue their work on central counterparty resilience, shadow banking, and over-the-counter derivatives reform [G20, 2015c].

To address two other major issues on the G20 financial agenda, the leaders asked the FSB to prepare a report on the implementation and effects of reforms [G20, 2015e]. This work was completed prior to the Antalya summit. The report, which will become annual, is considered by the Turkish G20 presidency to be "another critical output to monitor the impact" of decisions in the financial regulation area [Turkish G20 Presidency, 2015b]. 
The Turkish presidency's work on financial regulation issues largely built upon the previous years' results, and thus demonstrated a high level of continuity. At the same time, the launch of a mechanism for monitoring the implementation and assessing the effects of reforms through FSB annual reports is a major achievement reflecting the G20's leadership in the area, the sustainability of its decisions, and the pursuit of greater solidarity and acceptability (Table 9).

Table 9: Global Financial System Reform Assessment

\begin{tabular}{|l|c|}
\hline \multicolumn{1}{|c|}{ Criterion } & Score \\
\hline Leadership & 1 \\
\hline Solidarity & 1 \\
\hline Sustainability & 1 \\
\hline Acceptability & 1 \\
\hline Consistency & 1 \\
\hline Continuity & 1 \\
\hline
\end{tabular}

Source: compiled by the authors.

\section{Inclusive growth}

The Turkish presidency regarded inclusiveness as a priority in the domestic and global dimensions, and called it "one of the defining aspects" of its agenda. At the domestic level the presidency stressed that the benefits of growth and prosperity should be shared by all segments of society. Thus, the following issues were emphasized: small and medium-sized enterprises (SMEs) as "a cross-cutting subject," gender equality in employment, and youth unemployment. At the international level, tackling the challenges facing Low-Income Developing Countries (LIDCs) was prioritized [Turkish G20 Presidency, 2015a].

\section{Employment and SMEs}

The Turkish presidency emphasized that "creating better-quality jobs remains at the heart of G20's shared objective of achieving strong, sustainable and balanced growth." It was noted that the trend of persistent unemployment harms the economic performance of the G20 countries.

The G20's work in the area of employment during the Turkish presidency was focused on rising inequality in many countries, which "may pose risks to social cohesion and the well-being of our citizens and can also have negative economic impact and hinder our objective to lift growth" [G20, 2015c]. A comprehensive and balanced set of economic, financial, labour, education and social policies is needed for reducing inequality. At the Antalya summit the leaders endorsed the Declaration of G20 Labour and Employment Ministers, and committed to implementing its priorities to make labour markets more inclusive in line with the G20 Policy Priorities on Labour Income Share and Inequalities. The leaders asked the Finance, and Labour and Employment Ministers to review the G20 growth strategies and employment plans to strengthen action against inequality and to 
support inclusive growth. However, no timeframe for this review has been officially set. Recognizing that social dialogue is essential to advancing the goals, they welcomed the B20-L20 Joint Statement on Jobs, Growth and Decent Work.

One of the G20's key achievements in the area of employment was the adoption of a goal to reduce the share of young people who are most at risk of being permanently left behind in the labour market by $15 \%$ by 2025 in G20 countries. The G20 leaders committed to support better integration of the young people into the labour market including through the promotion of entrepreneurship. They asked the OECD and the ILO to assist in monitoring progress in achieving this goal.

The monitoring and assessment of G20 members' compliance with this commitment showed that the majority of members had taken action to contribute to achieving the goal. Three countries (India, South Korea and South Africa) took action to support higher youth employment, but no specific actions on the $15 \%$ goal were registered. No relevant actions taken by Indonesia were found. While the average level of compliance with this commitment was high (88\%), continuity of implementation should be ensured to reach the stated target of youth unemployment by 2025 [G20 Research Group, 2015].

The G20 reaffirmed the commitments contained in the national employment plans adopted in 2014, and committed to continue monitoring their implementation with a special focus on the goal of "reducing the gap in participation rates between men and women in [G20] countries by 25 per cent by 2025 , taking into account national circumstances." 12 The majority of G20 members fully complied with the commitment on monitoring the implementation of employment plans, with only Saudi Arabia showing partial compliance. Thus the average level for this commitment was $98 \%$.

The G20 also addressed such issues as international labour mobility and ageing populations. Recognizing domestic labour mobility as an important labour market issue in some G20 countries and pledging to further explore the potential of a flourishing silver economy, the G20 however did not take any specific actions on these issues. The leaders mandated the Labour and Employment Ministers to report on progress made in 2016.

On the issue of SME development, the G20 asked the International Chamber of Commerce, building on its extensive international network, to establish a World SME Forum. The forum should act as "a conduit to voice the expectations and concerns of the SME world to the Business-20 and the governments of the G20" [Turkish G20 Presidency, 2015a]. The creation of the forum was actively promoted and recommended by the B20 and is an example of effective cooperation between the B20 and G20. However, this private sector-led forum should be further institutionalized and funded to effectively serve as a global body, in order to facilitate the contributions of SMEs to growth and employment.

The G20 placed a special focus on promoting long-term financing for SMEs, and welcomed the Joint Action Plan on SME Financing, with the G20/OECD High-Level Principles on SME Financing as guidance [G20, 2015c].

The level of compliance on the commitment to support SMEs was relatively high (90\%), although several countries failed to take actions to integrate SMEs into the global value chains.

${ }^{12}$ G20 Leaders' Communiqué, Brisbane, November 16, 2014. Available at: http://www.g20. utoronto.ca/2014/2014-1116-communique.html (accessed 20 February 2017). 
The G20 showed good performance on almost all criteria. It showed leadership, sustainability and acceptability in committing to new specific long-term goals while securing strong support from outreach groups. However, the level of compliance on relevant commitments was uneven across G20 members, pointing to the need to increase solidarity within the G20. The discussion on employment and SME issues were interconnected and linked to other policy areas. The Turkish presidency continued the implementation of the previous summits' decisions and advanced them. Thus, consistency and continuity were assessed at high levels (Table 10).

Table 10: Employment and SMEs Assessment

\begin{tabular}{|l|c|}
\hline \multicolumn{1}{|c|}{ Criterion } & Score \\
\hline Leadership & 1 \\
\hline Solidarity & 0 \\
\hline Sustainability & 1 \\
\hline Acceptability & 1 \\
\hline Consistency & 1 \\
\hline Continuity & 1 \\
\hline
\end{tabular}

Source: compiled by the authors.

\section{Development cooperation}

2015 was a key year for international development cooperation, as the Sustainable Development Goals (SDGs) of the 2030 Agenda for Sustainable Development were adopted in September. Thus the Turkish G20 presidency put development at the centre of its agenda, with the primary focus on "further enhancing the integration of developing and low-income countries into the world economy." The following priorities were emphasized: improving investment environments and project preparation processes for infrastructure, broadening financial inclusion, reduction of the global average cost of transferring remittances, assisting developing and low-income countries in their efforts to benefit from the international tax agenda, supporting food security, human resource development, and enhancing the contribution of the private sector in development [Turkish G20 Presidency, 2015a].

At the Antalya summit, the G20 committed to support the 2030 Agendaimplementation, including the Sustainable Development Goals (SDGs) and the Addis Ababa Action Agenda to ensure "that no-one is left behind in our efforts to eradicate poverty and build an inclusive and sustainable future for all."

The G20 leaders adopted the G20 and Low-Income Developing Countries Framework to strengthen dialogue and engagement on development. They committed to develop an action plan in 2016 to further align the G20 work with the 2030 Agenda. This commitment was prioritized by the Chinese presidency in 2016.

The G20 endorsed the G20 Action Plan on Food Security and Sustainable Food Systems, aimed at improving global food security and nutrition and ensuring the way the countries "produce, consume and sell food is economically, socially and environmentally sustainable." The needs of smallholder and family farmers, rural women, and young people were highlighted as a particular priority. They also approved the decision of the G20 
Agriculture Ministers to establish a new platform to improve the way countries can measure and reduce food loss and waste.

The issue of the private sector's contribution to development was dealt with within the presidency. The G20 adopted the G20 Call on Inclusive Business and emphasized the need of all stakeholders to work together in order to promote opportunities for low-income people and communities to participate in markets as buyers, suppliers and consumers. The contribution of inclusive business which "can offer business opportunities, tapping into vast numbers of new customers" is estimated at around USD 5 trillion. However, no specific actions on partnership with businesses were mentioned in the document.

All G20 members, including the European Union, developed and submitted the National Remittance Plans. These include actions to implement the commitment on reducing the global average cost of transferring remittances to 5 percent. The leaders welcomed the continued work on financial inclusion within the Global Partnership for Financial Inclusion (GPFI), which helps to open up access to payments, savings, credit and other services.

The G20 members attained a low level of compliance with the commitment on reducing the average cost of transferring remittances (50\%). Only France, India, Italy, South Africa, and the European Union achieved full compliance and five members did not comply. At the same time, almost all G20 members except Mexico and South Africa fully complied with another development commitment - on Aid for Trade (95\%).

The G20 under the Turkish presidency improved deliberation, direction-setting and decision-making in the sphere of development and harmonized its agenda with the Sustainable Development Goals framework, thus demonstrating leadership, sustainability and acceptability. It continued relevant work made by previous presidencies and built the basis for future work on the issues under the Chinese presidency, showing a high level of continuity. However, it did not perform well on the solidarity criterion given the low average level of compliance with relevant commitments (Table 11).

Table 11: Development Cooperation Assessment

\begin{tabular}{|l|c|}
\hline \multicolumn{1}{|c|}{ Criterion } & Score \\
\hline Leadership & 1 \\
\hline Solidarity & 0 \\
\hline Sustainability & 1 \\
\hline Acceptability & 1 \\
\hline Consistency & 1 \\
\hline Continuity & 1 \\
\hline
\end{tabular}

Source: compiled by the authors.

\section{Enhancing legitimacy}

The outreach dialogue under the Turkish G20 presidency was a definite success. First, given that inclusiveness was one of the main presidency priorities (the "three I's") the G20 
attempted to reflect the interests of all groups of the international society. Second, a special part of the presidency priorities statement was devoted to the dialogue with the outreach partners ("countries, international organizations, civil society representatives, trade unions, research centers, and other NGOs”) [Turkish G20 Presidency, 2015a]. Thirdly, Turkey promoted its own and other G20 member states' high level of officials' participation in the outreach events, as well as outreach representatives' engagement in the G20 consultations. Fourth, the Turkish G20 presidency initiated and supported the establishment of a new outreach format - Women20 at the Leaders' level. Fifth, according to the B20 and C20 calculations, the level of inclusion of the outreach recommendation was high, e.g.: "out of B20's 19 recommendations submitted, 14 were directly or indirectly reflected in the Antalya G20 Leaders' Communiqué” [B20, 2015].

The modes of engagement with the outreach social partners such as the B20 predominantly included direct dialogue with the G20 Leaders, participation of outreach representatives in ministerial and other G20 meetings, references to the engagement groups' recommendations in the official G20 summit documents, etc. The modes of engagement with the representatives of the invited states and international organizations mainly included "cross-participation" in the events.

The Turkish G20 presidency's main innovation was regional consultation forums aimed at reaching out to the business community from emerging and non-G20 economies, and making their voice heard at the G20 level. B20 held nine regional forums with about 1000 participants in eight countries of Africa, Latin America, the Middle East and North Africa, South Asia, East Asia, and Eurasia. ${ }^{13}$ One of the forums was organized by the Turkish B20 presidency jointly with Russia's largest business association - the Russian Union of Industrialists and Entrepreneurs, (RSPP) in the framework of the St. Petersburg International Economic Forum (SPIEF) in June 2015.14 The Labour-20-B20-G20 engagement under the Turkish presidency was continued and consolidated. The L20 and B20 released a joint statement on "Jobs, Growth and Decent Work." 15

An important innovation of Turkey's outreach strategy was the establishment of a new G20 engagement group - Women-20 (W20), aimed at promoting gender-inclusive economic growth. The first summit of the W20 was held on 16-17 October 2015 in Istanbul. Turkish President Recep Tayyip Erdoğan delivered the opening speech of the summit. The W20 took a proactive stance, and signed a joint statement on gender equality with the C20 on the eve of the G20 summit with recommendations aimed at boosting the economic empowerment of women and their integration into the global economy, and submitted the Communiqué to the G20 Leaders with concrete indicators to develop a monitoring framework with regard to women's labor force participation rate, wage gaps, leadership positions, financial and digital inclusion, etc. [G20, 2015c]. The G20 leaders "blessed" the

${ }^{13}$ B20 Regional Forums, B20, Turkey. Available at: http://b20turkey.org/regional-forums/ (accessed 20 February 2017).

${ }^{14}$ RSPP held the B20 Regional Consultation Forum on the sidelines of the St. Petersburg International Economic Forum (SPIEF), RSPP. Available at: http://eng.rspp.ru/news/view/7352 (accessed 20 February 2017).

${ }^{15}$ Jobs, Growth and Decent Work. Available at: http://b20turkey.org/wp-content/uploads/ 2015/09/B20-L20-Statement.pdf (accessed 20 February 2017). 
W20 creation and expressed their expectations of its further active contributions to the G20 work in their Communiqué.

Although not all the recommendations of the C20 were reflected in the G20 Leaders' Communiqué, the G20 commitments aimed at promoting balanced and inclusive growth responded to the C20 message to the G20 under the Turkish presidency [C20, 2015].

The Think-20 differs from the B20, W20 and C20 as it is not an advocacy group, but rather a source of expertise. Three topics indicated in the Think-20 Chair's Statement [T20, 2015] were included in the G20 Leaders Communiqué, namely a reference to internet technology, "a new emphasis on the development of clean energy technologies," and "a call for a renewed effort for restructuring government debts." 16

The Turkish G20 presidency engaged in dialogue with young people. The Y20 Communiqué called on the G20 Leaders to set a "concrete, quantifiable and collective target on reducing youth unemployment" and the G20 Leaders in its Antalya Communiqué "agreed on the G20 goal of reducing the share of young people who are most at risk of being permanently left behind in the labour market by $15 \%$ by 2025 in G20 countries." It is fair to say that the Y20 recommendations influenced the G20 Leaders' decisions.

To sum up, the Turkish G20 presidency was committed to dialogue with engagement groups, which helped promote the G20's acceptability at the domestic and global level and inspired the institution's agenda with new ideas.

Turkey's choice of guest countries was determined by the tradition of inviting Spain and two African countries as guests, and the need to consolidate positions and strengthen relationships with one of its key regional partners - Azerbaijan. Turkey considers Azerbaijan to be a brotherly country, bound with Turkey by the principle of "one nation, two states." 17 So the set of the guest countries in the G20 in 2015 were Azerbaijan, Singapore, Malaysia as a country chairing ASEAN, Zimbabwe as the African Union chair, Senegal (presiding in the New Partnership for Africa's Development (NEPAD)), and Spain. The heads of the guest countries were invited to attend the G20 summit as well as ministerial and other G20 meetings. ${ }^{18}$

As did its predecessor (Australia), the Turkish presidency continued dialogue with the Caribbean countries. Although these countries are not in its direct sphere of interest, Turkey wished to ensure that the G20 decisions reflect the interests of the broader international community. For the first time in the G20's history a regional consultation with the countries of the Caribbean Community (CARICOM) was held on April 13, 2015 on the sidelines of the IMF and World Bank Spring Meetings in Washington DC. The meeting concluded with an outcome statement.

In comparison with the Australian G20 presidency, dialogue with the non-G20 member countries during the Turkish presidency was less intense, considering Australia's G20 Special Representative visits to the various regions, in particular the Middle East.

${ }^{16}$ The T20's recommendations were included in the G20 2015 Leaders Communique, TEPAV. Available at: http://www.tepav.org.tr/en/haberler/s/3956 (accessed 20 February 2017).

${ }^{17}$ Relations between Turkey and Azerbaijan. Available at: http://www.mfa.gov.tr/relationsbetween-turkey-and-azerbaijan.en.mfa (accessed 20 February 2017).

${ }_{18}$ Turkey Hosted the G20 Trade Ministers Meeting in Istanbul, G20. Available at: http://g20. org.tr/turkey-hosted-the-g20-trade-ministers-meeting-in-istanbul/ (accessed 20 February 2017). 
As did previous presidencies, Turkey actively engaged with international organizations. Special G20 side events were organized and the Turkish G20 presidency representatives addressed sessions of the IOs (e.g. the OECD). International organisations, including the UN, IMF, World Bank Group, OECD, WTO, ILO, FSB, FATF and BIS supported the G20 deliberation and decision making with their reports, research studies and other documents.

To sum up, the Turkish presidency's outreach dialogue made a meaningful contribution to its Inclusiveness priority and the acceptability of the outcomes.

\section{Conclusions}

The analysis shows that the G20 Turkish Presidency was a success in achieving the three main objectives of plurilateral summitry institutions: strengthening capacity for political leadership to launch new ideas and overcome deadlocks; reconciling domestic and international pressures; and consolidating collective management (Annex 1).

On most issue areas, the G20 showed a high level (1) of consistency in leaders' decisions across policy areas, and continuity with the previous presidencies' and the G20's core agenda. Sustainability and acceptability were also quite high (0.82), as the G20 ensured the longevity of the collectively produced solutions and received endorsement for the decisions from non-G20 countries' governments, international institutions and social partners. As at many previous summits, except Washington and London, G20 members were not able to agree on ambitious targets to boost trade and counteract the threat of multilateral trade system fragmentation, thereby demonstrating a lack of both leadership in crafting new commitments and solidarity in compliance with the pledges made. It should be noted, however, that although trade has been high on the G20 agenda since the forum's first summit, members' compliance performance has been disappointingly low. After the initial shock activated high-level compliance with the Washington and London anti-protectionist commitments ( $83.5 \%$ and $75 \%$ ), compliance seldom rose higher than the $65 \%$ achieved for Antalya. Thus, although the G20 was not able to harness enough political leadership to overcome the deadlock and forge a new far-reaching decision, it was able to deliver on the long standing anti-protectionist commitment relatively well.

The G20 displayed a very high level of performance across the six features of the summit institutions (leadership, solidarity, sustainability, acceptability, consistently and continuity) on all the Turkish G20 presidency's three priorities with a score of 1 on Investment and 0.92 on Inclusive Growth. Implementation, the presidency's third priority, also proved attainable at $78 \%$ for the summit, which is higher than the average for the G20 across summits, second only to Washington (83\%) and Los Cabos (79\%). The results confirm the findings from previous studies, that G20 compliance performance is higher on prioritized issues [Larionova et al., 2016]. We will be informed by future research whether the $\mathrm{G} 20$ is able to sustain and enhance this performance.

All in all, despite the numerous internal and external challenges, the G20 vessel arrived at its port of destination and fulfilled its mission under Turkey's stewardship. 


\section{References}

Avatkov V.A., Kochkin M.V. (2016) Osnovnye napravlenija krizisa vo vnutrennej i vneshnej politike Tureckoj Respubliki [Principle Trajectories of the Domestic and Foreign Policy Crises in Modern Turkish Republic]. Vestnik MGIMO-Universiteta, no 2. Available at: http://www.vestnik.mgimo.ru/ sites/default/files/pdf/001_avatkovva_kochkinmv_0.pdf (accessed 20 February 2016). (in Russian)

B20 (2015) Policy Achievements Assessment of Alignment with the Antalya G20 Leaders' Communique. Available at: http://b20turkey.org/wp-content/uploads/2015/11/B20-PolicyAchivements.pdf (accessed 10 February 2016).

Bayne N. (2005) Staying Together: The G8 Summit Confronts the 21st Century. Aldershot: Ashgate.

C20 (2015) C20 Turkey Verdict. Available at: http://c20turkey.org/uploads/C20\%20Turkey\%20 Verdict_FINAL_23.12.15.pdf (accessed 10 February 2017).

FSB (2015) The Common International Standard on Total Loss Absorbing Capacity for Global Systemically Important Banks. Available at: http://www.g20.utoronto.ca/2015/The-CommonInternational-Standard-on-Total-Loss-Absorbing-Capacity-for-Global-Systemically-ImportantBanks.pdf (accessed 10 February 2017).

G20 (2013) Advancing Transparency in Regional Trade Agreements. Available at: http://en.g20russia. ru/load/782788058 (accessed 10 February 2017).

G20 (2014) Brisbane Action Plan. Available at: http://www.g20.utoronto.ca/2014/brisbane_action_ plan.pdf (accessed 10 February 2017).

G20 (2015a) Communiqué of G20 Finance Ministers and Central Bank Governors. Available at: http://www.g20.utoronto.ca/2015/150905-finance.html (accessed 10 February 2017).

G20 (2015b) Communiqué of G20 Finance Ministers and Central Bank Governors. Available at: http://www.g20.utoronto.ca/2015/150417-finance.html (accessed 10 February 2017).

G20 (2015c) Leaders' Communiqué. Available at: http://www.g20.utoronto.ca/2015/151116communique.html (accessed 10 February 2017).

G20 (2015d) Antalya Action Plan. Available at: http://www.g20.utoronto.ca/2015/Antalya-ActionPlan.pdf (accessed 10 February 2017).

G20 (2015e) Communiqué of G20 Finance Ministers and Central Bank Governors. Available at: http://www.g20.utoronto.ca/2015/150210-finance.html (accessed 10 February 2017).

G20 (2015f) Communiqué: G20 Energy Ministers Meeting. Available at: http://www.g20.utoronto. ca/2015/151002-energy.html (accessed 10 February 2017). 
G20 (2015g) G20 Energy Access Action Plan: Voluntary Collaboration on Energy Access. Available at: http://www.g20.utoronto.ca/2015/G20-Energy-Access-Action-Plan.pdf (accessed 10 February 2017).

G20 (2015h) Action Plan on Food Security and Sustainable Food Systems. Available at: http:// www.g20.utoronto.ca/2015/G20-Action-Plan-on-Food-Security-and-Sustainable-Food-Systems. pdf (accessed 10 February 2017).

G20 (2015i) High-Level Principles on Private Sector Transparency and Integrity. Available at: http://www.g20.utoronto.ca/2015/G20-High-Level-Principles-on-Private-Sector-Transparencyand-Integrity.pdf (accessed 10 February 2017).

G20 (2015j) Introductory Note to the G20 Anti-Corruption Open Data Principles. Available at: http://www.g20.utoronto.ca/2015/G20-Anti-Corruption-Open-Data-Principles.pdf (accessed 10 February 2017$)$.

G20 (2015k) G20 Principles for Promoting Integrity in Public Procurement. Available at: http:// www.seffaflik.org/wp-content/uploads/2015/02/G20-principles-for-promoting-integrity-inpublic-procurement.pdf (accessed 10 February 2017).

G20 (20151) G20 High-Level Principles on Beneficial Owner Transparency (Spain). Available at: http://g20.org.tr/wp-content/uploads/2015/11/Spain-Written-Implementation-Plan-on-BO.pdf (accessed 10 February 2017).

G20 (2015m) G20 High-Level Principles on Beneficial Owner Transparency (Russia). Available at: http://g20.org.tr/wp-content/uploads/2015/11/Russia-Written-Implementation-Plan-on-BO.pdf (accessed 10 February 2017).

G20 Research Group (2015) 2015 G20 Antalya Summit Final Compliance Report. Available at: http://www.g20.utoronto.ca/compliance/2015antalya-final/index.html (accessed 10 February 2017).

G20, OECD (2015) Report on G20 Investment Strategies. Available at: http://g20.org.tr/wpcontent/uploads/2015/11/G20-Investment-Strategies-and-G20-OECD-Report-on-G20Investment-Strategies-Vol-2.pdf (accessed 10 February 2017).

IAIS (2015) Higher Loss Absorbency Requirements for Global Systemically Important Insurers. Available at: http://www.g20.utoronto.ca/2015/Higher-Loss-Absorbency-Requirements-forGlobal-Systemically-Important-Insurers.pdf (accessed 10 February 2017).

IMF (2014) World Economic Outlook (WEO). Legacies, Clouds, Uncertainties. Available at: http:// www.imf.org/external/pubs/ft/weo/2014/02/ (accessed 10 February 2017).

Larionova M.V., Rakhmangulov M.R., Shelepov A.V. (2016) Explaining G20 and BRICS Compliance. International Organisations Research Journal, vol. 11, no 3. pp. 99-131. Available at: https://iorj.hse.ru/en/2016-11-3/193354669.html (accessed 10 February 2017).

T20 (2015) Think-20 Chair's Statement. Available at: http://www.t20turkey.org/eng/pages/blog/ b43.html (accessed 10 February 2017). 
The Guardian (2015) Turkey Election 2015: A Guide to the Parties, Polls and Electoral System. Available at: https://www.theguardian.com/news/datablog/2015/oct/28/turkey-election-2015guide-parties-polls-electoral-system (accessed 10 February 2017).

Turkish G20 Presidency (2015a) Priorities for 2015. Available at: http://g20.org.tr/wp-content/ uploads/2014/12/2015-turkey-g-20-presidency-final.pdf (accessed 10 February 2017).

Turkish G20 Presidency (2015b) Fact-Sheet on G20 Antalya Summit Outcomes. Available at: http:// g20.org.tr/fact-sheet-g20-antalya-summit-outcomes/ (accessed 10 February 2017).

\section{Annex 1: Turkish presidency assessment}

\begin{tabular}{|c|c|c|c|c|c|c|c|c|c|c|c|c|}
\hline \multirow{2}{*}{ Criterion } & \multicolumn{4}{|c|}{ Strong Growth } & \multicolumn{2}{|c|}{$\begin{array}{l}\text { Sustainable } \\
\text { Growth }\end{array}$} & \multicolumn{3}{|c|}{ Balanced Growth } & \multicolumn{2}{|c|}{$\begin{array}{l}\text { Inclusive } \\
\text { Growth }\end{array}$} & \multirow[b]{2}{*}{ 窇 } \\
\hline & 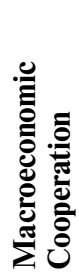 & 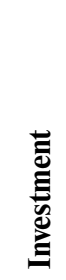 & 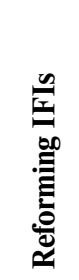 & 营 & 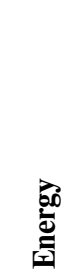 & 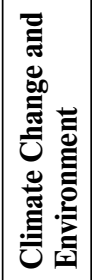 & 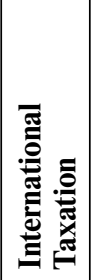 & 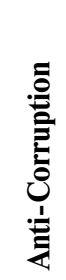 & 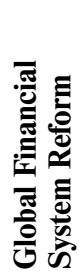 & 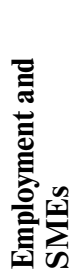 & 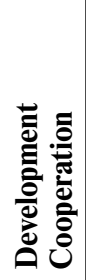 & \\
\hline Leadership & 1 & 1 & 0 & -1 & 1 & 0 & 1 & 1 & 1 & 1 & 1 & 0.64 \\
\hline Solidarity & 0 & 1 & 0 & -1 & -1 & 1 & 1 & 1 & 1 & 0 & 1 & 0.36 \\
\hline Sustainability & 0 & 1 & 1 & 0 & 1 & 1 & 1 & 1 & 1 & 1 & 1 & 0.82 \\
\hline Acceptability & 1 & 1 & 1 & 1 & 0 & 0 & 1 & 1 & 1 & 1 & 1 & 0.82 \\
\hline Consistency & 1 & 1 & 1 & 1 & 1 & 1 & 1 & 1 & 1 & 1 & 1 & 1.00 \\
\hline Continuity & 1 & 1 & 1 & 1 & 1 & 1 & 1 & 1 & 1 & 1 & 1 & 1.00 \\
\hline Average by policy areas & 0.67 & 1.00 & 0.67 & 0.17 & 0.50 & 0.67 & 1.00 & 1.00 & 1.00 & 0.83 & 1 & \\
\hline Average by growth goals & \multicolumn{4}{|c|}{0.63} & \multicolumn{2}{|c|}{0.58} & \multicolumn{3}{|c|}{1.00} & \multicolumn{2}{|c|}{0.92} & \\
\hline
\end{tabular}

